\title{
Development of technology for increasing well completion during drilling in the abnormal reservoir pressures intervals
}

\author{
Pierre Redrovan ${ }^{1, *}$, Vyacheslav Kuchin ${ }^{1}$ and Mikhail Dvoynikov ${ }^{2}$ \\ ${ }^{1}$ Graduate student, Department of well drilling, The St. Petersburg Mining University, 199106, 2, 21st Line, Saint Petersburg, Russia \\ ${ }^{2}$ Professor, Dean of the department of well drilling, The St. Petersburg Mining University, 199106, 2, 21st Line, Saint Petersburg, Russia
}

\begin{abstract}
Oil and gas resource production volumes in Russian fields are more confined to the development of areas discovered in the $70 \mathrm{~s}-80 \mathrm{~s}$. According to their operation and development level, a depletion of reserves and a decrease in reservoir pressure are observed. The long time for development contributes to the complication of well construction conditions in these fields, especially in the matter of ensuring the reliability of separation of discovered reservoirs. The analysis of drilling and completion materials for fields in North Siberia and the Artic region showed that the absorption value of cement slurries during well attachment has increased, as well as the presence of inter-reservoir flows.
\end{abstract}

\section{Introduction}

A significant proportion of the stock of producing wells is characterized by water cuts of more than $80 \%$. The well stock with water cuts immediately after development is at least $15 \%$.

We have to consider also the drilling bit, based on the measurements of the height of protrusion of the diamond from the matrix-type bits A4DP, the average (diamond size) number of diamond in contact with the wellbore was calculated depending on the depth of the diamond's intrusion. In doing so, the surface of the wellbore was considered smooth but rough for the bit [1-2].

It is possible to improving the quality of well completion in water influx conditions by using viscoelastic mixtures and regulating the over balance pressure during the initial drilling of an aquifer.

There are several ways of solving the problem of high-quality isolation of aquifers: selective isolation of water influx during remedial cementing, improving the the quality of well completion and temporary blocking the formation.

There are technologies that are already used to isolate intervals. An example of that is the use of the circulation sub.

The circulation sub is a circulation valve that allows you to repeatedly switch the fluid flow from the interior of the drill string to the annulus, there by bypassing all BHA elements located in the assembly below the sub [3].

This group of inventions relates mainly to the device and the method for selectively supplying fluid to a wellbore. Providing selective circulation of a fluid inside the wellbore, the possibility of a continuous drive of the valve, reducing the valve stroke.
The circulation sub was developed by DSI (A Schoeller-Bleckmann Company). For more than 20 years, the circulation sub has been widely used by leading drilling companies in all oil and gas producing regions of the world.

However, the use of this technology does not provide pressure control in the annular space.

\section{Aquifer opening technology}

The procedure for opening a productive formation is the final operation during oil and gas well construction. After a successful opening, all that remains is to test the well and put it into operation. In the event of an accident as a result of an unsuccessful drilling-in, the well can be repaired for a long time.

Moreover, the repair will have to be carried out at the expense of the drilling crew. Therefore, drillers pay special attention to opening. Various problems may appear at the time of opening a well such as:

1. The drilling tool may jam in the hole. There is usually a bit or bailer in the hole during the drilling

2. The time required for subsequent testing (pumping) of the well depends on the correct opening. An unsuccessful opening will lead to a decrease in the well production rate

The jamming of the drilling tool occurs due to the sand plug formed at the time of opening. In this case, the reservoir pressure, as a rule, becomes higher than the pressure at the bottom of the well. Water begins to flow rapidly into the well, carrying sand particles along with it.

The phenomenon is similar to the process of opening a bottle of sparkling water. Having unscrewed the cap, the water under the gas pressure is forced out of the bottle. It also happens in the well. Sand and heavy

* Corresponding author: pierre.redrovan@gmail.com 
particles settle and can form a plug. Therefore, it is very important to maintain a pressure in the well that exceeds the formation pressure when opening.

Typically, for this purpose, a drilling fluid is fed into the well at a pressure of usually about $0,051 \mathrm{MPa}$. At the time of opening, the flushing solution also flows into the aquifer.

\section{The use of various types of flushing solution when opening an aquifer}

The purpose of using the flushing solution is the primary strengthening of the borehole walls, cooling of the drilling tool, and removal of cuttings of destroyed rock at the wellhead.

There are the following types of flushing solution:

- solutions in which the main element is clay - clay solution;

- chalk-based solutions - chalk;

- water-hypane solutions;

- solution with the addition of air and foam - aerated;

- process water - often used as a flushing solution.

The choice of the composition of the solution is determined by the characteristics of the exposed aquifer.

When opening up stable rocks, a clay solution is not used, since the ingress of clay into the aquifer leads to clogging of the formation and the formation of plugs. The risk of plugging and tool seizure increases dramatically.

If the aquifer to be opened consists of fine-grained sand, then ordinary industrial water is used. For the opening of coarse-grained sandy horizons, chalk, aerated and water-hypane solutions are used. If the formation to be opened is formed by unstable rocks, then in the process of drilling, a clay solution is used, which is replaced with technical water immediately before opening.

For a correct opening, it is important to know exactly the depth at which it is located. Otherwise, there is a danger of opening the wrong layer or not the whole layer.

Special methods have been developed to accurately determine the depth of the aquifer

To ensure an better quality of well completion at intervals of uncontrolled influx, it is proposed to use a device with a pressure regulator with simultaneous injection of a viscoelastic system (Fig.1).

This device is installed in the BHA (bottom hole assembly), and the distance from the bit to the pressure regulator depends on the thickness of the aquifer thickness.

This paper considers the methodology for isolating water influx during the drilling of a reservoir with abnormally high formation pressures.

The technology of water influx during the drilling process is carried out by activating element number 4, providing a decrease / increase in the annular gap. In the process of overlapping (isolation), the viscoelastic system is injected.

The location of the device is set in accordance to the aquifer thickness. This condition is necessary so that the generated pressure is on the entire area of the blocked formation.

Next, the slug pill is pumped. As it goes through the interval, with the help of the flow rate, the pressure drop between the bottomhole and the element, the speed is adjusted without changing the diametrical section. This is done to create a fracture. In this case, the drill string always rotates.

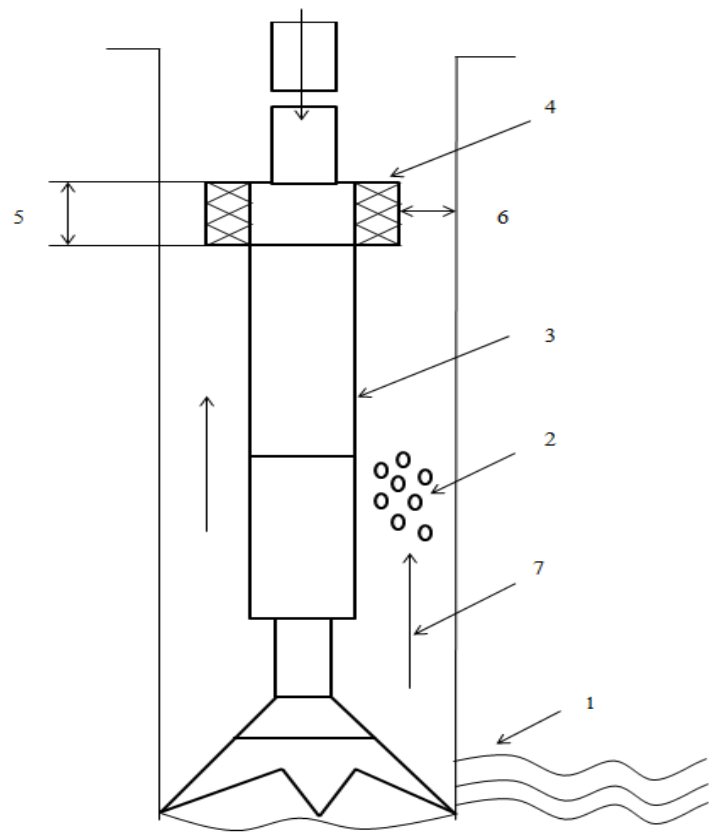

Fig. 1. Pressure regulator device with simultaneous injection of a viscoelastic system.

Where:

1. Aquifer (reservoir with abnormally high reservoir pressure);

2. The diameter of the mud particles;

3. BHA;

4. The device that regulates the gapping and creates a blocking pressure;

5. The height device that controls the distance to the rock;

6. The distance from the device 4 to the rock;

7. Drilling fluid.

\section{Methodology and Research Methods}

To conduct a computational experiment, it is necessary to know the well parameters: the well length, the fluid density, the viscosity and flow rate.

To apply this technology, the authors study the necessary literature, as well as further research and development.

To ensure high-quality well casing and their effective completion at a late stage of the operation while maintaining the reservoir properties of the reservoir, the main indicators of the blocking fluids that ensure trouble-free penetration of wells have been determined (table 1). Existing blocking fluids should meet these recommendations and take into account the geological 
conditions and possible complications, as some of these parameters can vary greatly.

Table 1. Recommended parameters of blocking fluids for work in low reservoir pressure conditions.

\begin{tabular}{|c|c|c|c|c|}
\hline \multirow{2}{*}{ Reagents } & \multicolumn{4}{|c|}{ Solutions } \\
\cline { 2 - 5 } & $\mathbf{1}$ & $\mathbf{2}$ & $\mathbf{3}$ & $\mathbf{4}$ \\
\hline Biopolymer & $2,6 \%$ & $1,5 \%$ & $1,5 \%$ & $0,5 \%$ \\
\hline SAS & $0,1 \%$ & $0,1 \%$ & $0,1 \%$ & $0,1 \%$ \\
\hline $\begin{array}{c}\text { Densifying } \\
\text { agent }\end{array}$ & $2,0 \%$ & $2,0 \%$ & $2,0 \%$ & $1,0 \%$ \\
\hline $\begin{array}{c}\text { PH } \\
\text { regulator }\end{array}$ & $0,06 \%$ & $0,06 \%$ & $0,06 \%$ & $0,06 \%$ \\
\hline \begin{tabular}{c} 
Bactericide \\
\hline
\end{tabular} & $0,05 \%$ & $0,05 \%$ & $0,05 \%$ & $0,05 \%$ \\
\hline
\end{tabular}

\begin{tabular}{|c|c|c|c|c|c|}
\hline \multirow{2}{*}{ Reagents } & \multicolumn{5}{|c|}{ Solutions } \\
\cline { 2 - 6 } & $\mathbf{5}$ & $\mathbf{6}$ & $\mathbf{7}$ & $\mathbf{8}$ & $\mathbf{9}$ \\
\hline Biopolymer & $\begin{array}{c}2,6 \\
\%\end{array}$ & $1,5 \%$ & $1,5 \%$ & $0,5 \%$ & $0,3 \%$ \\
\hline SAS & $\begin{array}{c}0,1 \\
\%\end{array}$ & $0,1 \%$ & $0,1 \%$ & $0,1 \%$ & $\begin{array}{c}0,04 \\
\%\end{array}$ \\
\hline $\begin{array}{c}\text { Densifying } \\
\text { agent }\end{array}$ & $\begin{array}{c}2,0 \\
\%\end{array}$ & $2,0 \%$ & $2,0 \%$ & $1,0 \%$ & $3,5 \%$ \\
\hline $\begin{array}{c}\text { PH } \\
\text { regulator }\end{array}$ & $\begin{array}{c}0,06 \\
\%\end{array}$ & $\begin{array}{c}0,06 \\
\%\end{array}$ & $\begin{array}{c}0,06 \\
\%\end{array}$ & $\begin{array}{c}0,06 \\
\%\end{array}$ & $\begin{array}{c}0,06 \\
\%\end{array}$ \\
\hline $\begin{array}{c}\text { Bactericide } \\
0,05\end{array}$ & $\begin{array}{c}0,05 \\
\%\end{array}$ & $\begin{array}{c}0,05 \\
\%\end{array}$ & $\begin{array}{c}0,05 \\
\%\end{array}$ & $\begin{array}{c}0,05 \\
\%\end{array}$ \\
\hline
\end{tabular}

Table 2. The composition of the investigated solutions.

\begin{tabular}{|c|c|}
\hline $\begin{array}{c}\text { The name of the indicators of } \\
\text { block fluid properties }\end{array}$ & $\begin{array}{c}\text { Recommended } \\
\text { value }\end{array}$ \\
\hline Density $\rho_{\text {foam }, \mathrm{kg} / \mathrm{m}^{3}}$ & $\begin{array}{c}\rho_{\text {foam }}=\rho_{\mathrm{m}}\left(\alpha_{0} / \mathrm{H}\right) \\
\text { less than } 1000\end{array}$ \\
\hline Expansion rate & $1,3-1,5$ \\
\hline Apparent viscosity, $\mathrm{s}$ & $100-500$ \\
\hline $\begin{array}{c}\text { Plastic viscosity, } \mathrm{MPa} * \mathrm{~s} \\
\text { nurface conditions } / \text { in } \\
\text { downhole conditions), DPa }\end{array}$ & $400-1000 / 150-700$ \\
\hline $\begin{array}{c}\text { Static shear stress } \theta 10 \mathrm{~s} / 10 \\
\text { min, } \mathrm{DPa}\end{array}$ & not less than $15 / 15$ \\
\hline $\begin{array}{c}\text { Filter rate } \Phi, \mathrm{cm}{ }^{3} / 30 \mathrm{~min} \\
\text { nymic shear stress } \tau \text { (in }\end{array}$ & not less than 5 \\
\hline
\end{tabular}

\begin{tabular}{|c|c|}
\hline Filter cake thickness, $\mathrm{mm}$ & $0,5-1,0 \mathrm{~mm}$ \\
\hline Hydrogen indicator $(\mathrm{pH})$ & $7-8$ \\
\hline Thermal stability, ${ }^{\circ} \mathrm{C}$ & to 90 \\
\hline Sedimentation stability, $\mathrm{kg} / \mathrm{m}^{3}$ & no more than 20 \\
\hline Daily settling \% & no more than 4 \\
\hline \multicolumn{2}{|c|}{$\begin{array}{l}\text { Legend: } \\
\text { ght of the foam column solution (volume } 100 \\
\qquad \mathrm{~cm}^{3} \text { ), } \mathrm{cm} ; \\
\mathrm{H} \text { - height of the foam column, } \mathrm{cm} \text {. }\end{array}$} \\
\hline
\end{tabular}

In accordance with the recommendations on the component composition in the laboratory, mixtures were prepared depending on which experimental studies were carried out [4]. The following reagents were chosen as the unchanged component of the solutions:

- sodium lauryl sulfate (surfactant - froth promoter and collecting agent);

- soda ash ( $\mathrm{pH}$ regulator, to soften water);

- biopol (biopolymer);

- calcium carbonate of different fractions (densifying agent, structure-forming agent);

- fused potassium acetic acid (bactericide).

The concentration of surfactants, stabilizing and structure-forming components varied. Table 2 presents the component compositions of the investigated solutions.

As the base compounds for their modification, in order to obtain formulations whose properties correspond to those recommended, compounds 7 and 9 were selected, since they have a minimum number of parameters that can be reduced to the necessary ones.

Table 3 presents the component compositions of the researched solutions.

Table 3. Chemical composition of tested solutions.

\begin{tabular}{|c|c|c|c|c|c|c|}
\hline \multirow{2}{*}{ Reagents } & \multicolumn{7}{|c|}{ Solutions, \% } \\
\cline { 2 - 7 } & $\mathbf{7}$ & $\mathbf{7 a}$ & $\mathbf{7 b}$ & $\mathbf{9}$ & $\mathbf{9 a}$ & $\mathbf{9 b}$ \\
\hline Biopolymer & 0,4 & 0,4 & 0,4 & 0,3 & 0,3 & 0,3 \\
\hline $\begin{array}{c}\text { Filter } \\
\text { regulator }\end{array}$ & - & 0,5 & 0,5 & - & 0,5 & 0,5 \\
\hline $\begin{array}{c}\text { Weighting } \\
\text { material }\end{array}$ & 2,0 & 2,0 & 1,0 & 3,5 & 3,5 & 0,7 \\
\hline $\begin{array}{c}\text { Surfactant } \\
\text { PH }\end{array}$ & 0,1 & 0,1 & 0,1 & 0,04 & 0,04 & 0,04 \\
\hline \begin{tabular}{c} 
Pegulator \\
\hline$y y y y y y$
\end{tabular} & 0,06 & 0,06 & 0,06 & 0,06 & 0,06 & 0,06 \\
\hline
\end{tabular}




\begin{tabular}{|l|l|l|l|l|l|l|}
\hline Bactericide & 0,05 & 0,05 & 0,06 & 0,05 & 0,05 & 0,06 \\
\hline
\end{tabular}

Table 4 Presents the results of studies of the proposed compositions.

Table 4. The main physic-chemical and rheological parameters of blocking liquid-gas mixture

\begin{tabular}{|c|c|c|c|c|c|c|}
\hline \multirow{3}{*}{$\begin{array}{c}\text { Properties } \\
\begin{array}{c}\text { Test } \\
\text { temperature }\end{array}\end{array}$} & \multicolumn{6}{|c|}{ Solution } \\
\hline & \multicolumn{2}{|c|}{7} & \multicolumn{2}{|c|}{$7 a$} & \multicolumn{2}{|c|}{$7 b$} \\
\hline & $\begin{array}{c}20^{\circ} \\
\mathrm{C}\end{array}$ & $\begin{array}{c}90^{\circ} \\
\mathrm{C}\end{array}$ & $\begin{array}{c}20^{\circ} \\
\mathrm{C}\end{array}$ & $\begin{array}{c}90^{\circ} \\
\mathrm{C}\end{array}$ & $\begin{array}{c}20^{\circ} \\
\mathrm{C}\end{array}$ & $\begin{array}{c}90^{\circ} \\
\mathrm{C}\end{array}$ \\
\hline $\begin{array}{c}\text { Density, } \mathrm{kg} \\
/ \mathrm{m}^{3}\end{array}$ & \multicolumn{6}{|c|}{$<1000$} \\
\hline $\begin{array}{c}\text { Apparent } \\
\text { viscosity, s }\end{array}$ & $\begin{array}{c}15 \\
0\end{array}$ & 140 & 170 & 160 & 260 & 240 \\
\hline Foam ratio & 1,5 & 1,5 & 1,6 & 1,6 & 1,42 & 1,4 \\
\hline $\begin{array}{c}\text { Stability, } \mathrm{kg} \\
\qquad / \mathrm{m}^{3}\end{array}$ & \multicolumn{6}{|c|}{0} \\
\hline $\mathrm{pH}$ & 7,6 & 7,2 & 7,2 & 7,2 & 7,2 & 7,2 \\
\hline $\begin{array}{l}\text { Filtration, } \\
\mathrm{cm}^{3} / 30 \mathrm{~min}\end{array}$ & 8,8 & 8,5 & 6 & 6,2 & 7 & 6,8 \\
\hline $\begin{array}{l}\text { The } \\
\text { thickness of } \\
\text { the filter } \\
\text { cake, } \mathrm{mm}\end{array}$ & 1,5 & 1,2 & 1,2 & 1,5 & 1,5 & 1 \\
\hline
\end{tabular}

\begin{tabular}{|c|c|c|c|c|c|c|}
\hline \multirow{3}{*}{$\begin{array}{c}\text { Properties } \\
\begin{array}{c}\text { Test } \\
\text { temperature }\end{array}\end{array}$} & \multicolumn{6}{|c|}{ Solution } \\
\hline & \multicolumn{2}{|l|}{9} & \multicolumn{2}{|c|}{$9 \mathrm{a}$} & \multicolumn{2}{|l|}{$9 b$} \\
\hline & $\begin{array}{c}20^{\circ} \\
\mathrm{C}\end{array}$ & $\begin{array}{c}90^{\circ} \\
\mathrm{C}\end{array}$ & $\begin{array}{l}20^{\circ} \\
\mathrm{C}\end{array}$ & $\begin{array}{c}90^{\circ} \\
\mathrm{C}\end{array}$ & $\begin{array}{c}20^{\circ} \\
\mathrm{C}\end{array}$ & $\begin{array}{c}90^{\circ} \\
\mathrm{C}\end{array}$ \\
\hline $\begin{array}{c}\text { Density, } \mathrm{kg} \\
/ \mathrm{m}^{3}\end{array}$ & \multicolumn{6}{|c|}{$<1000$} \\
\hline $\begin{array}{c}\text { Apparent } \\
\text { viscosity, s }\end{array}$ & $\begin{array}{c}27 \\
0\end{array}$ & 360 & 130 & 120 & 220 & 200 \\
\hline Foam ratio & 1,3 & 1,3 & 1,5 & 1,4 & 1,6 & 1,58 \\
\hline $\begin{array}{c}\text { Stability, } \mathrm{kg} \\
\qquad / \mathrm{m}^{3}\end{array}$ & \multicolumn{6}{|c|}{0} \\
\hline $\mathrm{pH}$ & 7,1 & 7,1 & 7,2 & 7,2 & 7,2 & 7,2 \\
\hline $\begin{array}{l}\text { Filtration, } \\
\mathrm{cm}^{3} / 30 \mathrm{~min}\end{array}$ & 8 & 8 & 8,4 & 8,2 & 8 & $\begin{array}{l}12,8 \\
(9- \\
\text { foa } \\
\mathrm{m})\end{array}$ \\
\hline $\begin{array}{c}\text { The } \\
\text { thickness of } \\
\text { the filter } \\
\text { cake, } \mathrm{mm}\end{array}$ & 1,5 & 1,3 & 1,2 & 1,2 & 1,5 & 1 \\
\hline
\end{tabular}

\section{Conclusion}

The most optimal solution that can be recommended for use was $9 \mathrm{~b}$. All the necessary parameters at this stage meets the required state.

Temporal isolation of permeable aquifers is a technologically necessary operation. This is significantly complicated at low reservoir pressures. Currently the compositions with low density is used. Examples of such formulations are emulsions and foams.

The most successful blocking fluids are fluids with a low dynamic shear stress in surface conditions and high in the near-wellbore zone of the formation, which reduces the likelihood of penetration of the kill fluid into the productive horizon and worsens its formation reservoir properties. High values of dynamic shear stress in surface conditions reduce the overall efficiency and the efficiency of the injection pump. Thus, the upcoming rheological studies should be aimed at checking the formulations obtained against these requirements, as well as developing new compounds in the event of a negative result.

\section{References}

1. V. G Gorelikov., Y.V. Lykov, Baatarkhuu Gantulga, International journal of applied engineering research ISSN 0973-4562 Volume 11 10, 7012-7016 (2016)

2. V.G. Gorelikov, Y.V. Lykov, L.K. Gorshkov, A.M Uspechov, International Journal of Engineering, Transactions B: Applications Volume 32 5, 790-793 (2019)

3. D. Schoeller-Bleckmann, Retrieved from SchoellerBleckmann D. Available online: $\underline{\text { http://sbdr.ru/catalog/2 (2015) }}$

4. M. V. Dvoinikov, M. V. Nutskova, V. N. Kuchin, Oil and gas and mining, 33-39 (2017)

5. R. Davis, Drilling 12, 70 (1989)

6. K. Fujii, W. Kondo, T. Wataabe, Cement-Klak-Gips, 2 (1970)

7. T. Garvin, P. Creel, OGJ 34, 125-126 (1984)

8. A. A. Ismailov, S. Z. Kabdulov, T. A. Tikebayev, International Journal of Chemical Sciences 11(1), 150-158 (2013)

9. E. I. Krasnova, O. P. Zotova, P. V. Sivkov, Academic Journal of Western Siberia 9(4(47), 17-18 (2013)

10. R. Montman, D. L. Sutton, W. M. Harms, Oil and Gas J 20, 219-232 (1983)

11. A. I. Piskunov, Problems of development of hydrocarbon and ore mineral deposits 1, 141-144 (2014)

12. S. D. Rozieres, R. Ferriere, SPE Prog. Eng. 3, $297-$ 304 (1991)

13. M. A. Silin, M. I. Rud, L. F. Davletshina, V. B. Gubanov, V. R. Magadov, L. A. Fedorova, F. Kh. Kyong, Construction of oil and gas wells on land and at sea 11, 11-13 (2010) 
14. M. Kh. Shamsutdinova, S. U. Goytemirova, E. L. Isaeva, H. Z. Bisieva, Y. N. Sirieva, Reflection 3, 50-54 (2010) 